\title{
Pengaruh Firm Performance, Firm Size, Leverage, Investment Opportunities terhadap Good Corporate Governance
}

\author{
Mouren Karnius Chandra dan Yusbardini \\ Program Studi Manajemen Fakultas Ekonomi \& Bisnis \\ Universitas Tarumanagara \\ Email: Mourenfive05@yahoo.com
}

\begin{abstract}
This study examines the impact of firm performance, firm size, leverage, and investment opportunities to good corporate governance. The sample in this study are 10 company which listed on the index CGPI report from 2016 until 2018 who selected through purposive sampling method. The result of this study are firm performance has no significant effect on good corporate governance, firm size has a significant positive effect on good corporate governance, leverage has a significant negative effect on good corporate governance, and investment opportunities has no significant effect on good corporate governance.
\end{abstract}

Keywords: Firm performance, Firm Size, Leverage, Investment Opportunities, Good Corporate Governance.

Abstrak: Penelitian ini bertujuan untuk menganalisis pengaruh Firm Performance, Firm Size, Leverage, dan Investment opportunities terhadap Good Corporate Governance. Sampel dari penelitian ini adalah 10 perusahaan yang terdaftar dalam laporan indeks CGPI periode 20162018 yang ditentukan menggunakan metode purposive sampling. Hasil dari penelitian ini adalah firm performance tidak berpengaruh secara signifikan terhadap good corporate governance, firm size memiliki pengaruh positif yang signifikan terhadap good corporate governance, leverage memiliki pengaruh negatif yang signifikan terhadap good corporate governance, dan investment opportunities tidak berpengaruh secara signifikan terhadap good corporate governance.

Kata Kunci: Firm performance, Firm Size, Leverage, Investment Opportunities, Good Corporate Governance.

\section{LATAR BELAKANG}

Saat ini tidak sedikit perusahaan yang berlomba-lomba untuk meningkatkan kemampuan dan kualitasnya di berbagai sektor agar perusahaannya dapat bertahan dan bersaing dipasar global. Salah satu upaya yang harus dilakukan guna meningkatkan kualitasnya adalah dengan menerapkan tata kelola perusahaan yang baik (Good Corporate Governance).

Good Corporate governance atau tata kelola perusahaan dinilai penting bagi manajemen perusahaan ataupun setiap pelaku dalam pasar. Corporate governance digunakan untuk melihat sejauh mana struktur perusahaan dan praktik perusahaan yang telah mereka lakukan. Selain itu, manfaat ekonomis bagi perusahaan yang menerapkan corporate governance adalah menjaga kelangsungan usaha, dan dapat meminimalkan potensi terjadinya suatu hal yang tidak di inginkan di dalam perusahaan, seperti kolusi, korupsi, dan nepotisme. Good corporate governance juga dapat meningkatkan kepercayaan baik investor maupun kreditor. Semakin baik pelaksanaan good corporate governance maka semakin baik juga respon yang diberikan investor terhadap kinerja perusahaan. 
Otoritas Jasa Keuangan (OJK) menilai good corporate governance menjadi cerminan bagi perekonomian suatu negara. Menurut Ketua Dewan Komisioner Otoritas Jasa Keuangan, Muliaman D Hadad, kegagalan penerapan good corporate governance suatu perusahaan dapat memperburuk perekonomian negara dan memicu timbulnya krisis ekonomi suatu negara. Oleh sebab itu Muliaman menghimbau untuk setiap perusahaan dapat menerapkan praktik good corporate governance sesuai dengan aturan yang ada supaya terciptanya perekonomian yang kuat dan berkesinambungan (Liputan6, 2014).

Sehingga dari hasil pemaparan latar belakang tersebut peneliti memutuskan untuk melakukan penelitian berjudul "Pengaruh Firm Performance, Firm Size, Leverage, Dan Investment Opportunities Terhadap Good Corporate Governance Pada Perusahaan Yang Terdaftar Dalam Laporan Indeks CGPI Periode 2016-2018”.

\section{KAJIAN TEORI}

Teori yang dibahas pada penelitian ini adalah Teori Keagenan. Pengelolaan perusahaan dan manjemen dalam perekonomian modern semakin banyak yang dipisahkan dari kepemilikannya. Hal ini sesuai dengan teori agensi yang pada dasarnya muncul karena perbedaaan penggunaan kewenangan antara agent dan principal yang memiliki tujuan berbeda. Didasari oleh teori keagenan, good corporate governance diharapkan mampu meyakinkan investor bahwa mereka akan menerima return atas dana yang telah mereka investasikan dan diharapkan juga mampu meyakinkan investor bahwa manajemen tidak akan menggelapkan atau menyelewengkan dana yang telah ditanamkan oleh investor.

Good Corporate Governance. merupakan suatu sistem atau aturan yang mengarahkan dan mengendalikan perusahaan dengan tujuan mencapai keseimbangan antara pemegang saham, manajer, kreditor, pemerintah, karyawan, dan pemangku kepentingan internal dan external lainnya sehubungan dengan hak dan tanggung jawab mereka.

Firm Performance. adalah pengukuran prestasi perusahaan yang ditimbulkan akibat dari proses pengambilan keputusan manajemen, yang kompleks dan sulit, karena menyangkut hubungan efektivitas pemanfaatan modal, efisiensi dan rentabilitas dari kegiatan perusahaan.

Firm Size. merupakan gambaran atas besarnya aset yang dimiliki oleh suatu perusahaan. Yang mana umumnya semakin besar ukuran perusahaan maka akan semakin besar pula total aset yang dimilikinya perusahaan tersebut.

Leverage. adalah suatu kebijakan yang dilakukan oleh perusahaan dalam menginvestasikan dana dan memperoleh sumber dana disertai dengan beban / biaya yang tetap harus perusahaan tanggung.

Investment Opportunities. menggambarkan tentang luasnya kesempatan investasi, yang mana nilai perusahaan dalam hal ini tergantung pada pilihan pembelanjaan (expenditure) perusahaan dimasa yang akan datang.

Menurut Jensen dan Meckling (1976), perusahaan yang dikelola dengan lebih baik mungkin memiliki operasi yang lebih efisien, dan ini akan menghasilkan pengembalian yang diharapkan (expected return) lebih tinggi. Oleh karena itu, perusahaan dengan sumber daya yang lebih besar lebih mungkin untuk mengembangkan sistem good corporate governance yang lebih maju, karena mereka dilengkapi dengan fasilitas untuk melakukannya.

Durnev \& Kim (2003) menyebutkan bahwa perusahaan besar cenderung menarik perhatian dan mungkin berada di bawah pengawasan yang lebih besar oleh pemangku 
kepentingan lainnya, sehingga hal tersebut mendorong perusahaan untuk menerapkan struktur tata kelola perusahaan yang lebih baik.

Menurut La Porta et al. (1999), perlindungan investor yang lebih besar akan meningkatkan kesediaan investor untuk menyediakan pembiayaan eksternal. Oleh karena itu, perusahaan dengan kebutuhan yang lebih besar untuk pembiayaan akan merasa bermanfaat untuk menerapkan mekanisme good corporate governance yang lebih baik.

Perusahaan yang mempunyai kesempatan investasi yang tinggi akan membutuhkan dana yang lebih besar. Jika kebutuhan dana internal perusahaan tidak tercukupi, maka perusahaan akan berusaha untuk mencari sumber dana ekternal. Debtholder yang mana dalam hal ini sebagai pihak ketiga akan melakukan evaluasi apakah perusahaan tersebut layak untuk diberikan pinjaman atau tidak. Hal yang dapat dilakukan oleh perusahaan guna mendapatkan kepercayaan debtholder salah satunya adalah dengan menerapkan good corporate governance yang baik.

Nelson Waweru (2013) dalam penelitiannya menyatakan bahwa firm performance berpengaruh positif signifikan terhadap kualitas good corporate governance. Menurut Asrudin Hormati (2009) menyatakan bahwa leverage memiliki pengaruh terhadap kualitas corporate governance, dan kesempatan investasi tidak memiliki pengaruh terhadap kualitas corporate governance. Ichsan Pamungkas (2012) menyatakan bahwa Ukuran perusahaan berpengaruh positif signifikan terhadap good corporate governance rating, namun leverage tidak berpengaruh signifikan terhadap good corporate governance rating. Dyah Rahayuningsih (2013) menyatakan bahwa investment opportunities, leverage, dan firm size tidak memiliki pengaruh terhadap kualitas good corporate governance.

\section{Hipotesis}

H1: Firm Performance berpengaruh terhadap Good Corporate Governance.

H2: Firm Size berpengaruh terhadap Good Corporate Governance.

H3: Leverage berpengaruh terhadap Good Corporate Governance.

H4: Investment opportunities berpengaruh terhadap Good Corporate Governance.

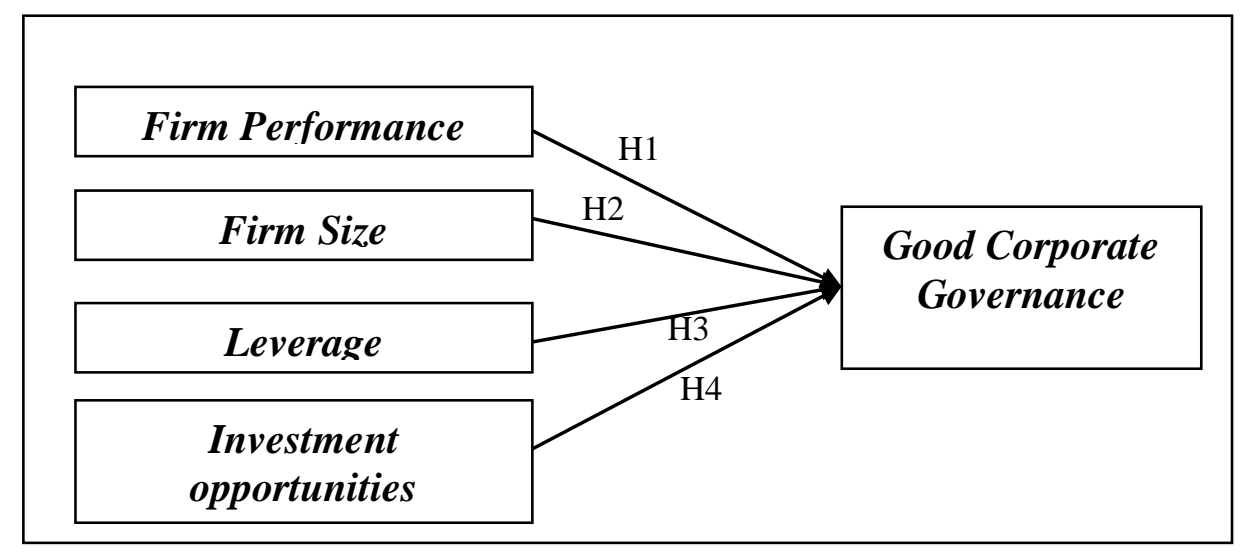

Gambar 1. Kerangka Pemikiran

\section{METODOLOGI}

Pada penelitian ini penulis menggunakan metode kuantitatif, serta desain penelitian bersifat deskriptif. Penelitian ini menggunakan data panel yang merupakan gabungan antara data time series dan cross-section. Pada penelitian ini terdapat empat variabel bebas sebagai penguji yakni firm performance, firm size, leverage, dan investment opportunities serta satu variabel terikat yakni good corporate governance. 
Subyek dalam penelitian ini adalah perusahaan yang terdaftar dalam laporan indeks CGPI periode 2016-2018. Data yang diambil merupakan laporan keuangan tahunan perusahaan dan diperoleh melalui website resmi BEI, yakni idx.co.id dan idnfinancials.com. Teknik yang digunakan pada penelitian ini adalah non-profitability dengan metode purposive sampling. Dari 49 perusahaan yang terdaftar dalam laporan indeks CGPI selama periode 2016-2018, setelah melalui teknik purposive sampling, jumlah sampel yang memenuhi kriteria dan dapat digunakan dalam penelitian adalah sebanyak 10 perusahaan. Data-data kemudian dikumpulkan ke dalam Microsoft Excel, lalu diolah menggunakan software Eviews 9.

\section{HASIL ANALISIS DATA \\ Hasil Uji Multikolinearitas}

Tabel 1. Hasil Uji Multikolinearitas

\begin{tabular}{|ccccc|}
\hline & ROE & SIZE & DER & MVEBVE \\
ROE & 1.000000 & 0.043944 & -0.208336 & -0.321219 \\
SIZE & 0.043944 & 1.000000 & 0.738911 & 0.551696 \\
DER & -0.208336 & 0.738911 & 1.000000 & 0.639167 \\
MVEBVE & -0.321219 & 0.551696 & 0.639167 & 1.000000 \\
\hline
\end{tabular}

Sumber data: Hasil didapat menggunakan Eviews 9

Berdasarkan hasil uji multikolinearitas yang dapat dilihat pada tabel di atas, tidak ada korelasi antar variabel independen yakni firm performance (ROE), firm size (SIZE), leverage (DER), investment opportunities (MVEBVE) yang melebihi 0,8. Hasil tersebut berarti bahwa tidak terjadi multikolinearitas antar variabel independen dalam penelitian ini pada perusahaan yang terdaftar laporan indeks CGPI periode 2016-2018.

\section{Hasil Analisis Statistik Deskriptif}

Tabel 2. Hasil Analisis Statistik Deskriptif

\begin{tabular}{|lrrrrr|}
\hline & CGPI & \multicolumn{1}{c}{ ROE } & SIZE & DER & MVEBVE \\
Mean & 86.29800 & 0.131253 & 32.52496 & 4.023194 & 224.8103 \\
Median & 87.74000 & 0.136603 & 32.89273 & 5.032975 & 234.3608 \\
Maximum & 93.86000 & 0.605024 & 34.79875 & 11.06456 & 888.4009 \\
Minimum & 72.68000 & -0.466665 & 29.51177 & -2.101554 & -1105.262 \\
Std. Dev. & 5.188929 & 0.159289 & 1.886705 & 3.362234 & 428.1847 \\
Skewness & -1.410948 & -0.855908 & -0.247643 & 0.058388 & -1.543531 \\
Kurtosis & 4.777825 & 10.06504 & 1.460390 & 2.497852 & 6.458639 \\
Jarque-Bera & 13.90471 & 66.05630 & 3.269633 & 0.332236 & 26.86517 \\
Probability & 0.000956 & 0.000000 & 0.194988 & 0.846946 & 0.000001 \\
Sum & & & & & \\
Sum Sq. & 2588.940 & 3.937584 & 975.7489 & 120.6958 & 6744.309 \\
Dev. & 780.8245 & 0.735819 & 103.2300 & 327.8339 & 5316923. \\
& & & & & \\
\hline
\end{tabular}




\begin{tabular}{|llllll|}
\hline Observations & 30 & 30 & 30 & 30 & 30 \\
\hline
\end{tabular}

Sumber data: Hasil didapat menggunakan Eviews 9

\section{Hasil Uji Chow}

Tabel 3. Hasil Uji Chow

\begin{tabular}{|lcrr|}
\hline \hline Effects Test & Statistic & d.f. & Prob. \\
\hline \hline Cross-section F & 214.170056 & $(9,16)$ & 0.0000 \\
Cross-section Chi-square & 143.990182 & 9 & 0.0000 \\
\hline
\end{tabular}

Sumber data: Hasil pengolahan menggunakan Eviews 9

Dari tabel hasil uji chow dapat dilihat bahwa nilai profitabilitas cross-section (Chi-square) sebesar 0,0000 yang dapat disimpulkan bahwa nilai tersebut $<0,05$ atau lebih kecil dari 0,05 sehingga dinyatakan bahwa $\mathrm{H}_{0}$ ditolak. Hal ini berarti fixed effects model merupakan model yang digunakan pada penelitian ini untuk melakukan estimasi terhadap data panel terkait.

\section{Hasil Uji Hausman}

Tabel 4. Hasil Uji Hausman

\begin{tabular}{|c|c|c|}
\hline \multicolumn{3}{|c|}{$\begin{array}{l}\text { Correlated Random Effects - Hausman Test } \\
\text { Equation: Untitled } \\
\text { Test cross-section random effects }\end{array}$} \\
\hline Test Summary & $\begin{array}{l}\text { Chi-Sq. } \\
\text { Statistic Chi-Sq. d.f. }\end{array}$ & Prob. \\
\hline Cross-section random & 9.409437 & 0.0516 \\
\hline
\end{tabular}

Sumber data: Hasil pengelolahan menggunakan Eviews 9

Berdasarkan hasil tabel diatas dapat dilihat bahwa probabilitas cross-section random > 0,05 maka H0 tidak ditolak berarti Random effect model lebih baik dalam mengestimasi data panel.

\section{Hasil Analisis Linear Berganda}

Tabel 5. Hasil Analisis Linear Berganda

\begin{tabular}{|ccccc|}
\hline \hline Variable & Coefficient & Std. Error & t-Statistic & Prob. \\
\hline \hline C & -13.55867 & 14.83140 & -0.914186 & 0.3694 \\
ROE & -1.268178 & 0.895954 & -1.415450 & 0.1693 \\
SIZE & 3.124912 & 0.468833 & 6.665294 & 0.0000 \\
DER & -0.413244 & 0.187952 & -2.198670 & 0.0374 \\
MVEBVE & 0.000214 & 0.000518 & 0.412422 & 0.6835
\end{tabular}




\begin{tabular}{|c|c|c|c|}
\hline \multicolumn{4}{|c|}{ Effects Specification } \\
\hline & & S.D. & Rho \\
\hline Cross-sec & tion random & 3.056335 & 0.9893 \\
\hline Idiosync1 & ratic random & 0.318106 & 0.0107 \\
\hline \multicolumn{4}{|c|}{ Weighted Statistics } \\
\hline R-squared & 0.663299 & Mean dependent var & 5.176403 \\
\hline Adjusted R-squared & 0.609427 & S.D. dependent var & 0.561377 \\
\hline S.E. of regression & 0.350837 & Sum squared resid & 3.077172 \\
\hline F-statistic & 12.31245 & Durbin-Watson stat & 1.158609 \\
\hline Prob(F-statistic) & 0.000011 & & \\
\hline
\end{tabular}

Sumber data: Hasil pengelolaan menggunakan Eviews 9

\section{Hasil Uji-F}

Tabel 6. Hasil Uji-F

\section{Dependent Variable: CGPI}

Method: Panel EGLS (Cross-section random effects)

Date: 05/30/20 Time: 13:04

Sample: 20162018

Periods included: 3

Cross-sections included: 10

Total panel (balanced) observations: 30

Swamy and Arora estimator of component variances

\begin{tabular}{|llll|}
\hline \hline F-statistic & 12.31245 & Durbin-Watson stat & 1.158609 \\
Prob(F-statistic) & 0.000011 & & \\
\hline \hline
\end{tabular}

Sumber data: Hasil pengelolaan menggunakan Eviews 9

Berdasarkan hasil tabel diatas dapat dilihat bahwa probabilitas (F-statistic) $<0,05$ maka, H0 ditolak berarti variabel firm performance (ROE), firm size (SIZE), leverage (DER), dan investment opportunities (MVEBVE) berpengaruh secara simultan/ bersamaan terhadap good corporate governance (CGPI).

\section{Hasil Uji-T}

Tabel 7. Hasil Uji-T

\begin{tabular}{l}
\hline Dependent Variable: CGPI \\
Method: Panel EGLS (Cross-section random effects) \\
Date: 05/30/20 Time: 13:04 \\
Sample: 2016 2018 \\
Periods included: 3
\end{tabular}




\begin{tabular}{|}
\begin{tabular}{l} 
Cross-sections included: 10 \\
Total panel (balanced) observations: 30 \\
Swamy and Arora estimator of component variances \\
\hline \hline Variable
\end{tabular} Coefficient & Std. Error & t-Statistic & Prob. \\
\hline \hline C & -13.55867 & 14.83140 & -0.914186 & 0.3694 \\
ROE & -1.268178 & 0.895954 & -1.415450 & 0.1693 \\
SIZE & 3.124912 & 0.468833 & 6.665294 & 0.0000 \\
DER & -0.413244 & 0.187952 & -2.198670 & 0.0374 \\
MVEBVE & 0.000214 & 0.000518 & 0.412422 & 0.6835 \\
\hline \hline
\end{tabular}

Sumber data: Hasil pengelolaan menggunakan Eviews 9

Nilai signifikansi probabilitas untuk variabel independen firm performance (ROE) adalah sebesar 0.1693, atau lebih besar dari 0,05. Maka artinya adalah berpengaruh tetapi tidak signifikan antara firm performance (ROE) terhadap good corporate governance (CGPI). Nilai signifikansi probabilitas untuk variabel independen firm size (SIZE) adalah sebesar 0.0000, atau lebih kecil dari 0,05. Maka artinya adalah terdapat pengaruh positif signifikan antara firm size (SIZE) terhadap good corporate governance (CGPI). Nilai signifikansi probabilitas untuk variabel independen leverage (DER) adalah sebesar 0.0374, atau lebih kecil dari 0,05. Maka artinya adalah terdapat pengaruh signifikan negatif antara leverage (DER) terhadap good corporate governance (CGPI).Nilai signifikansi probabilitas untuk variabel independen investment opportunities (MVEBVE) adalah sebesar 0.6835, atau lebih besar dari 0,05. Maka artinya adalah berpengaruh tapi tidak signifikan antara investment opportunities (MVEBVE) terhadap good corporate governance (CGPI).

\section{Hasil Uji Koefisien Determinasi $\left(\mathbf{R}^{\mathbf{2}}\right)$}

Tabel 8. Hasil Uji Koefisien Determinasi $\left(\mathrm{R}^{2}\right)$

\begin{tabular}{|llll|}
\hline \hline & & & \\
R-squared & 0.663299 & Mean dependent var & 5.176403 \\
Adjusted R-squared & 0.609427 & S.D. dependent var & 0.561377 \\
S.E. of regression & 0.350837 & Sum squared resid & 3.077172 \\
F-statistic & 12.31245 & Durbin-Watson stat & 1.158609 \\
Prob(F-statistic) & 0.000011 & & \\
\hline
\end{tabular}

Sumber data: Hasil pengelolaan menggunakan Eviews 9

Hasil koefisien determinasi di atas menunjukkan bahwa nilai $\mathrm{R}^{2}$ adalah sebesar 0.6094 yang memiliki arti bahwa pengaruh firm performance, firm size, leverage, dan investment opportunities terhadap good corporate governance adalah sebesar $60.94 \%$, kemudian sisanya $39.06 \%$ merupakan pengaruh dari variabel-variabel lain diluar dari penelitian ini. 
DISKUSI

\section{Pengaruh Firm Performance terhadap Good Corporate Governance}

Variabel independen yakni firm performance pada penelitian ini tidak memiliki pengaruh signifikan terhadap good corporate governance yang terdapat pada perusahaan yang terdaftar dalam laporan indeks CGPI periode 2016-2018. Hasil penelitian ini bertolak belakang dengan penelitian yang dilakukan oleh Nelson M. Waweru (2014) yang menyatakan bahwa firm performance memiliki pengaruh signifikan positif terhadap kualitas good corporate governance. Namun, hasil penelitian ini didukung oleh penelitian yang dilakukan oleh Bowo Sumanto (2014) yang menyatakan bahwa firm performance tidak memiliki pengaruh yang signifikan terhadap good corporate governance. Hal ini dapat terjadi karena, good corporate governance perlu diterapkan oleh setiap perusahaan tanpa harus melihat dari baik atau buruknya kinerja perusahaan tersebut. Dan perusahaan yang memiliki kinerja yang baik belum tentu memiliki kualitas corporate governance yang baik. Begitu juga sebaliknya, perusahaan yang memiliki kinerja yang buruk belum tentu memiliki kualitas corporate governance yang buruk.

\section{Pengaruh Firm Size terhadap Good Corporate Governance}

Variabel independen yakni firm size memiliki pengaruh yang signifikan serta positif dilihat dari coefficient terhadap good corporate governance yang terdapat pada perusahaan yang terdaftar dalam laporan indeks CGPI periode 2016-2018. Hasil penelitian ini bertolak belakang dengan penelitian yang dilakukan oleh Dyah Rahayuningsih (2013), yang menyatakan bahwa ukuran perusahaan tidak memiliki pengaruh signifikan terhadap good corporate governance.

Namun hasil penelitian ini didukung oleh hasil penelitian yang dilakukan oleh Asrudin Hormati (2009), dan Rachmawati Meitha \& Ulfa Tuzahro (2009) yang menyatakan bahwa ukuran perusahaan memiliki pengaruh signifikan positif terhadap kualitas corporate governance perusahaan. Semakin besar ukuran perusahaan maka akan semakin dipercaya oleh investor jika perusahaan menerapkan good corporate governance yang baik. Selain itu, semakin besar ukuran perusahaan maka akan semakin rumit sistem dan permasalahan yang akan perusahaan tersebut hadapi, sehingga menerapkan good corporate governance merupakan salah satu cara yang efektif dalam mengatasi permasalahan tersebut.

\section{Pengaruh Leverage terhadap Good Corporate Governance}

Variabel independen yakni Leverage pada penelitian ini memiliki pengaruh yang signifikan serta negatif dilihat dari coefficient terhadap good corporate governance yang terdapat pada perusahaan yang terdaftar dalam laporan indeks CGPI periode 2016-2018. Hasil penelitian ini tidak sejalan dengan penelitian yang dilakukan oleh Hasrudin Hormati (2009), dan Rachmawati Meitha \& Ulfa Tuzahro (2009), yang dalam penelitiannya menyatakan bahwa leverage tidak memiliki pengaruh signifikan terhadap good corporate governance.

Namun hasil penelitian ini sejalan dengan hasil penelitian yang dilakukan oleh Muh Donny Ramadhan, Moh Amin dan Junaidi (2017) dan Irmawatih (2016) yang juga menyatakan leverage memiliki pengaruh signifikan negatif terhadap good corporate governance. Perusahaan yang memiliki tingkat utang yang tinggi dalam struktur modalnya akan diawasi oleh kreditor secara ketat. Pengawasan ini dinyatakan dalam kontrak utang yang dibuat oleh pihak perusahaan dengan kreditur. Dengan demikian, perusahaan akan kurang mementingkan kualitas good corporate governance karena perusahaan merasa sudah ada pengawasan dari pihak eksternal. 
Pengaruh Investment Opportunities terhadap Good Corporate Governance

Variabel independen yakni investment opportunities pada penelitian ini tidak memiliki pengaruh signifikan terhadap good corporate governance yang terdapat pada perusahaan yang terdaftar dalam laporan indeks CGPI periode 2016-2018. Hasil penelitian ini tidak sejalan dengan hasil penelitian yang dilakukan oleh Rachmawati Meitha \& Ulfa Tuzahro (2009), dan Diah Ayu Setyani (2012) yang menyatakan bahwa investment opportunities memiliki pengaruh sginifikan terhadap good corporate governance.

Namun penelitian ini sejalan dengan penelitian yang dilakukan oleh Asrudin Hormati (2009) dan Dyah Rahayuningsih (2013), yang dalam penelitiannya menyatakan bahwa investment opportunities tidak memiliki pengaruh yang signifikan terhadap good corporate governance. Hal ini dapat terjadi karena perusahaan yang memiliki kesempatan investasi yang tinggi tidak berarti akan meningkatkan kualitas praktik corporate governance. Perusahaan yang memiliki kesempatan investasi yang tinggi memang membutuhkan pendanaan yang besar, namun jika dana internal perusahaannya masih mampu mencukupi, sehingga tidak membutuhkan dana dari pihak eksternal, maka hal tersebut membuat perusahaan merasa tidak perlu untuk meningkatkan kualitas praktik good corporate governance guna menarik kepercayaan investor untuk mendapatkan dana eksternal.

\section{KESIMPULAN}

Pada penelitian yang diteliti ini, peneliti mempunyai keterbatasan yang di dapat, yakni sampel yang digunakan sebagai subjek pada penelitian ini hanya menggunakan perusahaanperusahaan yang terdaftar dalam laporan indeks CGPI, periode yang diteliti hanya selama 3 tahun, yakni pada tahun 2016 hingga 2018, peneliti hanya meneliti 4 variabel terhadap good corporate governance perusahaan yakni firm performance, firm size, leverage dan investment opportunities, peneliti tidak mampu meneliti seluruh variabel yang yang mampu mempengaruhi good corporate governance dikarenakan keterbatasan waktu. Saran yang dapat dijadikan tolak ukur atau bahan pertimbangan terhadap peneliti berikutnya menambahkan jumlah sampel yang lebih luas, diharapkan kepada peneliti berikutnya untuk tidak hanya menggunakan subjek perusahaan-perusahaan yang terdaftar dalam laporan indeks CGPI saja. Peneliti berikutnya diharapkan menambah variabel independen lain untuk memberikan pertimbangan kepada pihak manejer perusahaan berkaitan dengan faktor yang memiliki dampak terhadap good corporate governance.

\section{DAFTAR PUSTAKA}

Ariyanti, Fiki. (2014). Tata Kelola Perusahaan Buruk Jadi Pemicu Krisis Ekonomi Dunia. Retrieved March 25, 2020, from https://www.liputan6.com/bisnis/read/817550/tata-kelola-perusahaan- buruk-jadipemicu-krisis-ekonomi-dunia

Donny Ramadhan, Muh.,Moh Amin., Junaidi. (2017). Pengaruh Karakteristik Perusahaan Dan Ukuran Perusahaan Terhadap Kualitas Implementasi Corporate Governance (Studi Empiris Pada Perusahaan Manufaktur Yang Terdaftar Di BEI Periode 2013-2016. Skripsi. Universitas Islam Malang.

Durnev, A., dan Kim, E.H. (2003). To steal or Not to Steal: Firm Attributes, Legal Environment, and Valuation. Working Paper.

Hormati, Asrudin. (2009). "Karakteristik Perusahaan Terhadap Kualitas Implementasi Corporate Governance". Jurnal Keuangan dan Perbankan, Vol. 13, No. 2 Mei 2009, hal. $288-298$. 
Irmawatih. (2016). "Analisis Faktor-Faktor Yang Mempengaruhi Good Corporate Governance Pada PT. Adira Dinamika Multi Finance Tbk. Cabang Makasar".Skripsi, Manajemen Universitas Islam Negeri Alauddin Makasar.

Jensen, Michael C. dan W.H. Meckling. (1976). Theory of The Firm: Managerial Behavior, Agency Cost and Ownership Structure. Journal of Financial Economics 3. Hal 305360.

La Porta, R. et.al. (1999). Corporate Ownership Around the World. Journal of Finance. Vol. 54. No.2 Pp 471-577.

Meitha, Rachmawati dan Ulfa Tuzahro. (2009). Determinan Corporate Governnace. Jurnal Akuntansi Indonesia 5(2):273- 285.

Pamungkas, Ichsan dan Dul Muid. (2013). Analisis Faktor-Faktor yang Mempengaruhi Good Corporate Governance Rating (Studi Kasus pada Perusahaan yang Terdaftar Dalam Laporan Indeks CGPI Tahun 2009-2011). Diponegoro Journal of Accounting. Volume 2, No. 3, hal. 376-386.

Rahayuningsih, Dyah. (2013). Pengaruh Kesempatan Investasi, Konsentrasi Kepemilikan, Leverage, Komposisi Aktiva, Ukuran Perusahaan, Dan Faktor Regulasi Terhadap Kualitas Good Corporate Governance. Jurnal Dinamika Akuntansi Vol. 5, No. 2, September 2013, pp. 135-145

Sumanto, Bowo dkk. (2014). Pengaruh Kepemilikan Institutional dan ukuran dewan Komisaris Terhadap Manajemen Laba. Accounting Analysis Journal 3 (1) (2014). ISSN 22526765.

Waweru, Nelson. (2013). "Factors influencing quality corporate governance in Sub Saharan Africa: an empirical study". Managerial Auditing Journal Vol. 14 No.4 2014, pp. 555-574. 